\title{
HUBUNGAN POLA ASUH ORANGTUA DAN HARGA DIRI ANAK JALANAN USIA REMAJA
}

\author{
Puji Mentari*, Novy Helena Catharina Daulima
}

Fakultas Ilmu Keperawatan Universitas Indonesia, Depok 16424, Indonesia

*E-mail: fuji.mentari29@gmail.com

\begin{abstract}
Abstrak
Fenomena anak jalanan merupakan fokus perhatian banyak kalangan karena jumlahnya yang terus meningkat. Penelitian sebelumnya menyebutkan bahwa anak jalanan memiliki harga diri yang rendah dan identik dengan pola asuh uninvolved. Desain penelitian ini menggunakan deskriptif korelatif yang bertujuan mengidentifikasi hubungan pola asuh orangtua dan harga diri anak jalanan usia remaja. Penelitian ini dilakukan di daerah binaan rumah singgah di Jakarta Timur dengan 98 sampel, diambil menggunakan metode consecutive sampling. Harga diri diukur dengan menggunakan Rosenberg's Self Esteem Scale dan pola asuh diukur dengan Instrumen Pola Asuh Mashoedi yang dikembangkan dari teori pola asuh orangtua milik Diana Baumrind. Hasil analisis menunjukkan bahwa terdapat hubungan antara pola asuh orangtua dengan tingkat harga diri anak jalanan usia remaja di Jakarta Timur $(p=0,04)$. Untuk menangani masalah anak jalanan, diperlukan kerjasama dari pemerintah, perawat komunitas, pekerja sosial dan pihak rumah singgah untuk bersama-sama melakukan pemberdayaan anak jalanan berbasis keluarga dalam upaya merehabilitasi anak jalanan.
\end{abstract}

Kata kunci: anak jalanan, harga diri, pola asuh orangtua, remaja

\begin{abstract}
Relationship of Parenting Style and Self-Esteem of Street Children the Teen Years. The phenomenon of street children is a matter that has become the focus by many people because the number of street children itself is always increasing. Previous research stated that the street children have low self-esteem and they are identical with uninvolved parenting style. It is descriptive correlative study which aims to identify the relationship between parenting style and self-esteem on street children at East Jakarta. This research was conducted in the target area of shelter in East Jakarta towards 98 samples recruited using consecutive sampling. Self-esteem is measured using Rosenberg's Self Esteem Scale and parenting style measured using Mashoedi's Parenting Style which was developed from the theory of Diana Baumrind's parenting style. The results showed, there is a relationship between parenting style and a level of selfesteem street children in East Jakarta $(p=0.04)$. To overcome the problem of street children, the cooperation between governments, community nurses, social workers and shelter is needed to do the family-based empowerment together to rehabilitate street children.
\end{abstract}

Keywords: Street children, self-esteem, parenting style, adolescent

\section{Pendahuluan}

Fenomena anak jalanan merupakan masalah sosial yang sangatlah kompleks. United Nations (UN) memperkirakan terdapat kurang lebih 150 juta anak jalanan di dunia, jumlah ini akan semakin benambah dari tahun ke tahun (Street Children, 2010) dan 50 juta diantara jumlah anak jalanan di dunia berada di benua Asia (Abid \& Aslam, 2011). Di Indonesia, menurut data
Kementerian Sosial Republik Indonesia (2013) jumlah anak jalanan pada tahun 2013 mencapai 33.400 jiwa. Jumlah anak jalanan terbanyak ada di Jakarta yaitu 7315 anak $(21,9 \%$ dari jumlah keseluruhan anak jalanan pada 2013) (Kementerian Sosial Republik Indonesia [Kemensos], 2013). Anak jalanan berisiko mengalami banyak masalah seperti masalah fisik yaitu kurang gizi, polusi lingkungan, ancaman terhadap keselamatan fisik yaitu rawan per- 
kelahian, siksaan anak yang lebih besar, tindakan kasar dari orang-orang sekitar (Mayaut, 2005). Selain itu, anak jalanan diidentikkan dengan bebas, liar, tanpa aturan, dekat dengan perilaku negatif seperti mencuri, berkelahi, ngelem, pengguna narkoba dan seks bebas oleh masyarakat (Saripudin, 2012). Berbagai problematika dan labelisasi membangun sebuah stigma pada diri anak-anak yang hidup di jalanan sehingga pada akhirnya menciptakan harga diri rendah pada anak tersebut (Ezeokana, Ebi-Nwuso, \& Okoye, 2014).

Jenis pola asuh orangtua yang terbentuk didasarkan pada dua dimensi yaitu dimensi pengendalian dan dimensi responsive penerimaan (Baumrind, 1971 dalam Deshpande \& Chhabriya, 2013). Dari dua dimensi tersebut akan membentuk empat jenis pola asuh yaitu authoritative, authoritarian, permissive dan uninvolved (Boyd $\&$ Bee, 2006). Pola asuh yang diberikan orangtua sangat berhubungan dengan pembentukan harga diri anak (Martínez \& García, 2007).

Anak jalanan yang menghabiskan sebagian besar waktu di jalan cenderung diasuh dengan pola asuh penelantaran orangtuanya (Novyaningrum, 2011). Pola asuh penelantaran tentunya akan membentuk harga diri yang rendah pada anak jalanan tersebut. Harga diri rendah dapat menyebabkan depresi, gangguan makan, mudah tersinggung serta berisiko mengalami perilaku bunuh diri, anorexia nervosa dan identik melakukan kenakalan (Wu, Chen, Yang, Ding, Yang, H., \& Sun, 2015). Berdasarkan uraian tersebut, penulis tertarik untuk melihat hubungan antara pola asuh terhadap pembentukan harga diri pada anak jalanan, disamping juga ingin mendapatkan gambaran karakteristik anak jalanan dan harga diri yang terbentuk.

\section{Metode}

Desain penelitian yang digunakan adalah deskriptif korelatif. Sampel yang digunakan dalam penelitian ini berjumlah 98 orang anak jalanan usia remaja di Jakarta Timur dengan kriteria sampel adalah berada di wilayah binaan empat rumah singgah di Jakarta Timur, masih tinggal bersama orangtua, berusia 11-18 tahun, bisa membaca dan menulis serta bersedia mengikuti penelitian ini. Sampel diambil dengan metode consecutive sampling, teknik sampel ini merupakan teknik sampe non random sampling yang digunakan karena penulis tidak memiliki kerangka sampel penelitian.

Harga diri anak jalanan usia remaja di Jakarta Timur diuukur dengan menggunakan instrumen Rosenberg's Self Esteem Scale yang terdiri dari 10 item. Intrumen kedua yang digunakan dalam untuk mengukur pola asuh yang terbentuk dalam penelitian ini adalah instrumen pola asuh Mashoedi. Instrumen ini terdiri dari 40 pernyataan yang terbentuk dari dua dimensi pola pengasuhan Baumrind (1971) yaitu dimensi pengendalian (Demanndingness) dan dimensi penerimaan (Responsiveness).

Kedua instrumen ini memiliki nilai validitas dan reliabilitas yang baik. Intrumen Rosenberg's Self Esteem Scale (RSES) menunjukkan hasi uji validitas dan reliabilitas yang berada antara 0,415 sampai dengan 0,703 bagi kesepuluh item dalam skala $(\mathrm{n}=71)($ Azwar, 1979). Instrumen untuk mengukur pola asuh orangtua Mashoedi telah dilakukan uji validitas dan reliabilitas yang hasilnya 0,83 untuk dimensi pengendalian dan 0,93 untuk dimensi penerimaan.

Analisis data dilakukan pada data univariat dan bivariat. Analisa univariat dilakukan dengan menggunakan uji distribusi frekuensi untuk data kategorik (usia, jenis kelamin, pendidikan, penghasilan, pekerjaan, tingkat harga diri dan jenis pola asuh orangtua). Sedangkan untuk analisa bivariat menggunakan uji kai kuadrat untuk menganalisis karakteristik responden dan pola asuh orangtua yang dihubungkan dengan tingkat harga diri anak jalanan.

\section{Hasil}

Gambaran Karakteristik Responden. Karakteristik responden yang diteliti dalam penelitian ini terdiri dari usia, jenis kelamin, tingkat 
pendidikan, perkerjaan, dan penghasilan anak dalam sehari. Pada Tabel 1 menunjukkan hasil bahwa anak jalanan mayoritas berada pada usia remaja awal $(55,1 \%)$, laki-laki (70\%), tidak bersekolah $(40,8 \%)$, dan pengamen $(40,85)$.

Gambaran Pola Asuh Orangtua. Pola asuh orangtua yang diukur dengan menggunakan instrumen Mashoedi menunjukkan hasil bahwa pola asuh yang paling banyak diterapkan oleh orangtua anak jalanan di Jakarta Timur adalah pola asuh authoritative $(30,6 \%)$ (lihat pada Tabel 2).

Gambaran Harga Diri Anak Jalanan. Hasil penelitian menunjukkan bahwa anak jalanan di Jakarta Timur lebih banyak yang memiliki harga diri tinggi (51\%) (lihat Tabel 3).
Hubungan Karakteristik Responden dengan Tingkat Harga Diri Anak Jalanan Usia Remaja. Hasil analisis hubungan antara karakteristik dan harga diri anak jalanan menunjukkan bahwa terdapat hubungan antara tingkat pendidikan dan tingkat harga diri anak jalanan usia remaja ( $p=0,044 ; \alpha=0,05)$ (lihat Tabel 4).

Hasil uji bivariat pada karaktertik responden berupa penghasilan dalam sehari menunjukkan hasil rata-rata pengasilan anak jalanan yang memiliki harga diri tinggi adalah Rp63.540,-, sedangkan untuk anak jalan yang memiliki harga diri rendah penghasilannya Rp40.000,-. Hasil uji menunjukkan bahwa terdapat hubungan antara penghasilan yang didapat sehari dengan tingkat harga diri anak jalanan usia remaja di Jakarta Timur $(p=0,005 ; \alpha=0,05)$.

Tabel 1. Distribusi Karakteristik Anak Jalanan

\begin{tabular}{|c|c|c|}
\hline Karakteristik & Jumlah (n) & Persentase (\%) \\
\hline \multicolumn{3}{|l|}{ Usia } \\
\hline Remaja Awal & 54 & 55,1 \\
\hline Remaja Tengah & 24 & 24,5 \\
\hline Remaja Akhir & 20 & 20,4 \\
\hline \multicolumn{3}{|l|}{ Jenis Kelamin } \\
\hline Laki-Laki & 67 & 70 \\
\hline Perempuan & 31 & 30 \\
\hline \multicolumn{3}{|l|}{ Tingkat Pendidikan } \\
\hline Tidak Bersekolah & 40 & 40,8 \\
\hline SD & 34 & 34,7 \\
\hline SMP & 18 & 18,3 \\
\hline SMA & 6 & 0,06 \\
\hline \multicolumn{3}{|l|}{ Pekerjaan } \\
\hline Pedagang Asongan & 22 & 22,4 \\
\hline Pemulung & 18 & 18,3 \\
\hline Pengamen & 40 & 40,8 \\
\hline Pengemis & 1 & 0,01 \\
\hline Ojek Payung & 3 & 0,03 \\
\hline Kondektur Kopaja & 8 & 0,08 \\
\hline Parkir & 2 & 0,02 \\
\hline Pekerja Pasar & 3 & 0,03 \\
\hline
\end{tabular}

Tabel 2. Distribusi Anak Jalanan Menurut Pola Asuh Orangtua

\begin{tabular}{ccc}
\hline Pola Asuh & $\begin{array}{c}\text { Jumlah } \\
(\mathbf{n})\end{array}$ & Persentase (\%) \\
\hline Authoritative & 30 & 30,6 \\
Permisive & 24 & 24,4 \\
Authoritarian & 18 & 18,3 \\
Unininvolved & 26 & 26,5 \\
\hline
\end{tabular}


Tabel 3. Distribusi Anak Jalanan Menurut Harga Diri

\begin{tabular}{ccc}
\hline Pola Asuh & Jumlah (n) & Persentase (\%) \\
\hline Harga Diri Tinggi & 50 & 51 \\
Harga Diri Rendah & 48 & 49 \\
\hline
\end{tabular}

Tabel 4. Distribusi Anak Jalanan Menurut Usia, Jenis Kelamin, Pendidikan, Pekerjaan dengan Harga Diri

\begin{tabular}{lcccc}
\hline \multicolumn{1}{c}{ Karakteristik } & \multicolumn{2}{c}{ Haraga Diri Tinggi } & \multicolumn{2}{c}{ Harga Diri Rendah } \\
\cline { 2 - 5 } & $(\mathbf{n})$ & $\mathbf{( \% )}$ & $\mathbf{( n )}$ & $\mathbf{( \% )}$ \\
\hline Usia & & & & \\
Remaja Awal & 19 & 46,3 & 22 & 53,7 \\
Remaja Tengah & 18 & 50 & 18 & 50 \\
Remaja Akhir & 13 & 61,9 & 8 & 38 \\
Jenis Kelamin & & & & \\
Laki-Laki & 33 & 50,7 & 32 & 49,2 \\
Perempuan & 17 & 51,5 & 16 & 48,5 \\
Tingkat Pendidikan & & & & \\
Tidak Bersekolah & 17 & 53,6 & 24 & 46,4 \\
SD & 16 & 45,7 & 19 & 54,2 \\
SMP & 12 & 75 & 4 & 25 \\
SMA & 5 & 83,3 & 1 & 16,7 \\
Pekerjaan & & & & \\
Pedagang Asongan & 8 & 36,4 & 14 & 63,6 \\
Pemulung & 11 & 61,1 & 7 & 38,8 \\
Pengamen & 22 & 55 & 19 & 47,5 \\
Pengemis & 1 & 100 & 0 & 0 \\
Ojek Payung & 1 & 33,3 & 2 & 66,7 \\
Kondektur Kopaja & 5 & 62,5 & 3 & 37,5 \\
Parkir & 1 & 50 & 1 & 50 \\
Pekerja Pasar & 1 & 33 & 2 & 67 \\
\hline
\end{tabular}

Tabel 5. Distribusi Anak Jalanan Menurut Pola Asuh Orangtua dan Harga Diri

\begin{tabular}{lccccc}
\hline \multirow{2}{*}{ Pola Asuh } & \multicolumn{2}{c}{ Harga Diri Tinggi } & \multicolumn{2}{c}{ Harga Diri Rendah } \\
\cline { 2 - 5 } & $(\mathbf{n})$ & $\mathbf{( \% )}$ & $\mathbf{( n )}$ & $(\boldsymbol{\%})$ \\
\hline Authoritative & 18 & 18,3 & 12 & 12,2 \\
Permisive & 16 & 16,3 & 8 & 8,1 \\
Authoritarian & 8 & 8,1 & 10 & 10,2 \\
Unininvolved & 8 & 9,1 & 18 & 18,3 \\
\hline
\end{tabular}

Hubungan Pola Asuh Orangtua dan Harga Diri Anak Jalanan Usia Remaja di Jakarta Timur. Pada bagian ini ditampilkan hubungan antara variabel pola asuh dan harga diri anak jalanan usia remaja di Jakarta Timur. Pada Tabel 5 menunjukkan hasil analisis hubungan antara pola asuh orangtua dengan harga diri anak jalanan menunjukkan terdapat hubungan antara pola asuh orangtua dengan harga diri yang terbentuk pada anak $(p=0,04 ; \alpha=0,05)$.

\section{Pembahasan}

Hubungan Karakteristik Responden dan Harga Diri. Hasil penelitian menunjukkan mayoritas responden merupakan anak jalanan yang berusia 11-13 tahun. Hasil penelitian sebelumnya, melaporkan semakin besar usia seorang anak, maka semakin sedikit jumlah populasi anak jalanan. Hal ini disebabkan oleh semakin besar usia anak, akan semain berusaha untuk 
mendapat pekerjaan yang lebih stabil dengan upah yang lebih baik (Ibrahim, 2012). Sehingga pada akhirnya, anak jalanan yang berusia lebih kecil akan lebih banyak terlihat bekerja di jalanan.

Penelitian ini menunjukkan bahwa tidak ada hubungan antara harga diri dan usia anak jalanan. Meskipun tidak menunjukkan hubungan yang saling terkait, hasil penelitian ini menunjukkan jumlah anak jalanan yang memiliki tingkat harga diri tinggi sedikit lebih banyak daripada anak yang memiliki harga diri rendah. Hasil ini sejalan dengan penelitian lain yang dilakukan Erol dan Orth (2011). Penelitian-penelitian tersebut menyebutkan bahwa harga diri mengalami peningkatan sepanjang usia dan pada usia remaja terjadi peningkatkan tingkat harga diri. Namun, peningkatan tingkat harga diri usia remaja bertolak belakang dengan Robin, et al., (2005) yang menyatakan bahwa harga diri mengalami penurunan pada remaja karena remaja mengalami transisi berbagai kejadian dalam hidup dari masa anak-anak ke remaja.

Inkonsistensi berbagai hasil penelitian mengenai tingkat harga diri pada usia remaja dapat disebabkan karena pada usia remaja terdapat faktor lain lebih yang dapat memengaruhi harga diri anak tersebut diantaranya jenis kelamin (McMullin \& Cairin, 2004), penerimaan orangorang terdekat (Gecas, 1972), tingkat pendidikan dan penghasilan.

Hasil penelitian terhadap anak jalanan di Jakarta Timur ini juga menunjukkan bahwa responden anak jalanan dengan jenis kelamin laki-laki lebih banyak daripada perempuan. Hasil ini sesuai dengan penelitian yang dilakukan oleh Ezeokana, et al. (2011) yang melakukan penelitian mengenai pada anak jalanan di Nigeria yang menunjukkan hasil bahwa jumlah anak jalanan laki-laki 277 orang dan perempuan sebanyak 135 orang ( $n=412$ anak). Fenomena anak jalanan yang didominasi oleh laki-laki karena kecenderungan bahwa anak-anak perempuan lebih banyak dituntut membantu orang- tua bekerja dengan mengurusi rumah atau menjaga adik yang masih kecil (Purwoko, 2013). Selain itu, pengaruh budaya yang menuntut anak perempuan lebih diatur oleh keluarga, sehingga lebih banyak anak laki-laki yang terlihat bekerja di jalanan daripada anak perempuan.

Hasil penelitian menunjukkan bahwa tidak ada hubungan antara jenis kelamin dan harga diri. Hasil penelitian ini sama dengan penelitian yang dilakukan oleh Erol dan Orth (2011) yang menyatakan bahwa antara jenis kelamin dan harga diri tidak berhubungan. Sehingga harga diri tidak dapat dibedakan berdasarkan jenis kelamin. Selain itu, salah satu hal yang membedakan antara harga diri perempuan dan laki-laki adalah hubungan interpersonal, perempuan lebih memperhatikan hubungan interpersonal sedangkan laki-laki berfokus pada diri sendiri (El Ravei, 2008).

Anak jalanan sering membentuk kelompok komunal antar sesama anak jalanan yang dapat terdiri dari anak berjenis kelamin laki-laki atau perempuan (Lefa, 2014). Hal tersebut menunjukkan bahwa anak jalanan baik perempuan dan laki-laki memiliki hubungan interpersonal yang tinggi dengan sesama anak jalanan ditunjukan dengan solidaritas yang sangat tinggi (Andari, 2013). Sehingga harga diri yang tinggi dapat terbentuk tidak memandang perbedaan jenis kelamin pada anak tersebut. Selain itu, jumlah responden anak jalanan laki-laki lebih banyak 2 (dua) kali lipat dari responden anak jalanan perempuan pada penelitian ini. Ketimpangan jumlah responden ini juga dapat menyebabkan hasil penelitian yang bias sehingga menyebabkan tidak terdapat hubungan antara jenis kelamin dan tingkat harga diri.

Pada penelitian anak jalanan usia remaja di Jakarta Timur ditemukan bahwa pekerjaan anak jalanan yang paling dominan adalah menjadi pengamen. Pada penelitian ini didapatkan hasil bahwa tidak ada hubungan antara pekerjaan yang dilakukan anak jalanan dengan tingkat harga diri. Hal ini tidak sesuai dengan teori 
yang menyebutkan individu yang memiliki pekerjaan, pendapatan tinggi serta menempati kelas sosial ekonomi tinggi akan memunculkan harga diri yang lebih tinggi (Coopersmith, 1981).

Survei yang dilakukan oleh Kemensos (2013) menunjukkan bahwa mayoritas $(72,25 \%)$ anak jalanan bekerja dan berada di jalan karena alasan ekonomi. Anak-anak tersebut ingin membantu ekonomi orangtua dan menambah biaya sekolah. Jika ditinjau dari teori kebutuhan Abraham Maslow (1970) mengenai "Hirearchy of Needs" yang membagi kebutuhan manusia ke dalam lima tingkatan. Pada anak jalanan yang bekerja di jalan untuk memenuhi kebutuhan ekonominya menunjukkan bahwa anakanak tersebut sedang berusaha memenuhi psychological needs. Psychological needs merupakan kebutuhan dasar yang harus dipenuhi terlebih dahulu sebelum memenuhi kebutuhan lainnya. Ketika anak tersebut masih berusaha memenuhi kebutuhan pada tingkat paling dasar maka kebutuhan yang ada di tingkat yang lebih tinggi belum dapat dipenuhi. Sehingga jenis pekerjaan yang dijalani anak tersebut di jalan tidak memengaruhi tingkat harga dirinya.

Hasil penelitian anak jalanan usia remaja di Jakarta Timur menunjukkan tingkat pendidikan yang ditempuh anak jalanan usia remaja di Jakarta Timur tergolong rendah bahkan mayoritas sudah putus sekolah dan sebagian besar hanya mencapai tingkat SD. Hasil ini juga sejalan dengan SUSENAS yang dilakukan Badan Pusat Statistik (BPS) pada tahun 2012 yang menyebutkan bahwa sebanyak 409.144 (20,54 $\%$ ) anak terlantar (termasuk anak jalanan) di Indonesia sudah tidak bersekolah lagi (Kemensos, 2013).

Dalam penelitian ini dapat dilihat bahwa terdapat hubungan antara tingkat pendidikan dan harga diri anak jalanan. Penelitian ini mendapatkan bahwa semakin tinggi tingkat pendidikan yang ditempuh anak jalanan semakin banyak anak yang memiliki harga diri tinggi. Gecas dan Seff (1989) menyebutkan bahwa efek dari pendidikan terhadap harga diri sangatlah tinggi dibandingkan dengan pekerjaan.

Pada penelitian ini, ditemukan bahwa terdapat hubungan antara penghasilan dan tingkat harga diri. Hasil ini bertentangan dengan hasil penelitian dari McMullin dan Cairney (2004) yang menyebutkan bahwa penghasilan memengaruhi harga diri pada usia dewasa dan lansia namun tidak memengaruhi pada remaja. Pada penelitian McMullin dan Cairney (2004) responden remaja yang terlibat pada penelitian tersebut merupakan remaja di sekolah formal dan belum memiliki penghasilan sendiri, berbeda dengan responden remaja pada penelitian ini yang merupakan anak jalanan yang sudah bekerja dan memiliki penghasilan sendiri. Penghasilan berhubungan dengan tingkat harga diri karena penghasilan akan memengaruhi nilai dan persepsi individu dalam memandang dirinya sendiri. Dapat disimpulkan bahwa anak jalanan yang sudah bekerja dan memiliki penghasilan sendiri menunjukkan bahwa semakin tinggi penghasilan maka harga diri yang terbentuk semakin tinggi.

\section{Hubungan Pola Asuh Orangtua dan Harga}

Diri. Pola asuh orangtua yang terbanyak pada penelitian ini adalah pola asuh authoritative yaitu pengasuhan yang demokratis, hangat dan flekibel. Orangtua yang menerapkan pola asuh ini ditandai dengan pola kehangatan, menerapkan disiplin tanpa hukuman, konsisten dalam bertindak serta diimbangi dengan kehadiran yang penuh dalam kehidupan anak (Milevsky, Schecter, Netter, \& Keehn, 2007). Pola asuh authoritative merupakan pola asuh terbaik yang dapat diterapkan orangtua pada anak (Baumrind, 1971).

Hasil penelitian ini yang menunjukkan pola asuh authoritative memiliki persentase yang lebih tinggi pada anak jalanan tidak sesuai dengan penelitian Noviyaningrum (2011) pada anak jalanan yang ada di Jombang yang menunjukkan bahwa anak jalanan menunjukkan pola pengasuhan keluarga yang mengalami penelantaran (uninvolved). 
Terdapat perbedaan yang mencolok antara penelitian ini dengan penelitian Noviyaningrum (2011). Hal ini dapat disebabkan pada kedua penelitian ini terdapat perbedaan metode penelitian yang digunakan. Penelitian ini menggunakan metode kuantitatif sedangkan pada penelitian Noviyaningrum yang menggunakan metode penelitian kualitatif. Hasil penelitian Novyaningrum (2011) menunjukkan bahwa jawaban lebih mendalam yang didapatkan melalui wawancara.

Pembentukan pola asuh authoritative yang lebih besar pada anak jalanan usia remaja di Jakarta Timur menunjukkan bahwa tidak ada pengaruh keputusan seorang anak dengan pola asuh yang dibentuk oleh orangtua anak tersebut. Hal ini didukung dengan penelitian yang dilakukan oleh Kemensos (2013) yang hasilnya menunjukkan bahwa $79 \%$ anak jalanan bekerja di jalan disebabkan karena faktor ekonomi dan sebagian besar turun ke jalan tanpa paksaan orangtuanya. Sehingga dapat disimpulkan bahwa pola asuh yang terbentuk pada anak jalanan usia remaja di Jakarta Timur merupakan pola asuh yang baik dan tidak dipengaruhi oleh keberadaan anak di jalan

Kehidupan jalanan yang keras, kurangnya perhatian dari orangtua, keharusan untuk mandiri khususnya dalam ekonomi, lingkungan yang kurang kondusif, dan kurang pendidikan merupakan faktor yang mendorong terbentuknya konsep diri negatif di anak jalanan (Fitri, 2007 dalam Fawzie \& Kurniawati, 2012).

Hasil penelitian ini bertentangan dengan konsep di atas, penelitian ini menunjukkan bahwa jumlah anak jalanan yang memiliki harga diri positif sedikit lebih banyak daripada harga diri negatif. Hal ini dapat disebabkan meski anak jalanan sering didiskriminasikan, tidak dihargai, memiliki kehidupan yang keras di jalanan, kurang perhatian dalam keluarga yang akhirnya memicu timbulnya harga diri rendah. Namun demikian, terdapat faktor lain yang dapat meningkatkan tingkat harga diri anak tersebut. Anak-anak tersebut sangat diterima dan me- miliki hubungan yang sangat erat dengan teman sesama anak jalanan sehingga mereka tidak memiliki harga diri negatif.

Hal ini didukung oleh penelitian Andari (2013) yang menyebutkan bahwa tingkat solidaritas antar sesama anak jalanan sangat tinggi. Solidaritas antar sesama anak jalanan ini terjalin karena kesamaan latar belakang keluarga yang miskin, kesamaan usia serta tekanan eksternal dan internal yang diiterima anak tersebut di jalanan (Andari, 2013). Penerimaan teman sebaya sesama anak jalanan didukung oleh Lefa (2014) yang menyatakan bahwa pengaruh grup teman sebaya pada anak jalanan sangatlah tinggi karena anak-anak jalanan tersebut membutuhkan penerimaan dan perlindungan yang mereka dapatkan dari lingkungan grup teman sebaya sesama anak jalanan.

Pada penelitian ini, responden anak jalanan berusia remaja. Berdasarkan teori perkembangan, remaja pada dasarnya memiliki keinginan yang besar untuk memiliki grup yang hubungannya dapat sangat erat dan memberikan status kepada remaja tersebut. Selanjutnya, Guzman (2007) menyatakan bahwa masa remaja merupakan masa ketika penerimaan teman sebaya merupakan hal yang memegang peranan penting dalam kehidupan.

Penerimaan teman antar sesama anak jalanan yang memengaruhi harga diri anak jalanan menjadi positif, didukung oleh Pamela dan Waruwu (2006) yang menyebutkan bahwa perasaan diterima oleh suatu kelompok merupakan salah satu aspek pembentuk harga diri tinggi. Selain itu, teori yang dikemukakan oleh Rosenberg, Schooler, dan Schoenbach (1995) menyebutkan bahwa teman dan gambaran diri merupakan faktor yang berkontribusi paling besar dalam memengaruhi harga diri seorang remaja. Kesimpulannya, pada penelitian ini jumlah anak yang memiliki harga diri positif anak jalanan di Jakarta Timur lebih tinggi dapat diasumsikan dipengaruhi oleh penerimaan teman sebaya sesama anak jalanan dan juga pola asuh yang dibentuk orangtua. 
Hasil penelitian ini menunjukkan bahwa terdapat hubungan antara pola asuh orangtua dan tingkat harga diri anak jalanan. Hubungan antara pola asuh dan harga diri didukung oleh penelitian yang dilakukan Milevsky, Schlecter, Netter, dan Keehn (2007) yang menyatakan bahwa anak yang diasuh oleh orangtua yang menerapkan pola asuh authoritative memiliki harga diri yang tinggi daripada anak yang pola asuh orangtua authoritarian dan permissive.

Orangtua yang menerapkan pola asuh authoritative orangtua memberikan kebebasan kepada anak. Anak akan menunjukkan perkembangan emosional, social, dan kognitif yang baik, serta membentuk anak yang memiliki harga diri tinggi dan rasa percaya diri yang baik bila diasuh dengan pola asuh authoritative.

Hasil penelitian ini menunjukkan bahwa anak yang diasuh dengan pola asuh authoritative dan permisive akan menciptakan lebih banyak anak yang memiliki harga diri anak yang tinggi sedangkan orangtua yang menerapkan pola asuh authoritarian dan uninvolved akan menciptakan anak yang memiliki harga diri rendah. Hasil ini sesuai dengan teori yang menyebutkan orangtua yang yang hangat, responsive (authoritative) akan meningkatkan harga diri anak, sedangkan orangtua yang perfeksionis, suka mngeritik, terlalu mengontrol (authoritarian), mengabaikan atau tidak memberi batasan serta kontrol yang jelas (uninvolved) akan menurunkan harga diri anak.

\section{Kesimpulan}

Hasil penelitian ini menunjukkan bahwa anak jalanan usia remaja di Jakarta Timur mayoritas berada pada tahap remaja awal. Mayoritas anak jalanan usia remaja di Jakarta Timur berjenis kelamin laki-laki, bekerja sebagai pengamen, berpendidikan rendah dan berpenghasil-

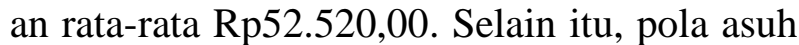
yang terbentuk merupakan pola asuh yang authoritative. Harga diri yang tinggi dimiliki oleh sebagian besar anak jalanan.
Hasil penelitian menunjukkan bahwa terdapat hubungan antara tingkat pendidikan dan penghasilan dengan tingkat harga diri anak jalanan, namun tidak ditemukan hubungan antara usia, jenis kelamin dan pekerjaan dengan pembentukan harga diri pada anak jalanan usia remaja. Penelitian ini juga menunjukkan adanya hubungan antara pola asuh orangtua dan tingkat harga diri anak jalanan. Pola asuh authoritative membentuk lebih banyak anak jalanan usia remaja yang memiliki harga diri tinggi, sedangkan pola asuh uninvolved membentuk anak yang memiliki harga diri rendah. Adanya hubungan antara pola asuh orangtua dan harga diri pada anak jalanan merupakan salah satu hal yang dapat dijadikan dasar untuk melakukan rehabilitasi anak jalanan yang berbasis keluarga $(\mathrm{NH}, \mathrm{NN}, \mathrm{AR})$.

\section{Referensi}

Abid, S., \& Aslam, N. (2011). Internalizing and externalizing problem in children: A Comparison of street and non street children. Pakistan Journal of Clinical Psychology, 10 (2), 17-29.

Andari, S. (2013). Solidaritas sebagaistrategi survival anak jalanan (studi kasus di Lempuyangan Yogyakarta). Yogyakarta: Balai Besar Penelitian dan Pengembangan Kesehateraan Sosial.

Badan Pusat Statistika. (2013). Penduduk Indonesia menurut Provinsi 1971, 1980, 1990, 1995, 2000 dan 2010. Februari, 23 2015. Diperoleh dari http://www.bps.go.id/ tab_sub/view.php?kat=1\&tabel $=1 \&$ daftar $=1$ \&id_subyek $=12 \&$ notab $=1$.

Baumrind, D. (1971). Current patterns of parental authority. Depelovment Psychology, 4 (1, Pt.2), 1-103. http://dx.doi.org/10.1037/h003 0372.

Boyd, D., \& Bee, H. (2006). Lifespan development. Boston: Pearson Education Inc.

Coopersmith, S. (1981). The antecendents of self esteem. California: Consulting Psychologist Press. 
Desphande, A., \& Chhabariya, M. (2013). Parenting style and its effects on adolscents's self esteem. International Jornal of Innovations in Enginering and Technology (IJIET), 2 (4), 310-315.

El Ravei, S. (2008). The relationship beetwen self esteem and gender, grade level, and academic achievment in secondary sschools classes in Lebanon. University Leicester.

Erol, R.Y., \& Orth, U. (2011). Self esteem development from age 14 to 30 years: A longitudinal study. Journal of Personality and Social Phsyicology, 101 (3), 607-619. doi: 10.1037/a0024299.

Ezeokana, J., Ebi-Nwuso, H., \& Okoye, C., (2014). Influence of street life and gender on aggression and self esteem in a sample Nigerian Children. International Review of Management and Business Research, 3 (2), 949-959.

Fawzie, Z.C., \& Kurniati, S. (2012). Faktor lingkungan yang membentuk konsep diri pada anak jalanan. Jurnal Stikes, 5 (1), 2137.

Gecas, V., \& Seff. (1989). Parental behavioral and contextual variations in Adolscent self esteem. Sociometry, 35 (2), 332-345.

Guzman, M.R.T. (2007). Friendships, peer influence, and peer pressure during the teen years. United State: University of NebraskaLincoln.

Ibrahim. (20120). Characteristics of street children. E-International Relations Students. University of Birmingham.

Kementerian Sosial RI. (2014). Profil anak terlantar di Indonesia. Jakarta: Kemensos RI.

Lawrence, A., \& Lawrence, D. (1996). Self esteem and your children: A guide to happy parenting. Knightsbridge: Minerva Press.

Maslow, A. (1970). Motivation and personality (2nd Ed.). New York: Harper \& Row.
Mayaut, F.G. (2005). Anak jalanan dalam pendekatan ilmu pekerjaan sosial. INSANI, 9.

McMullin, J.A., \& Cairney, A. (2004). Self-esteem and intersectionof age, class, and gender. Journal of Aging Studies, 18, 75-90. doi: 10.1016/j.jaging.2003.09.006.

Milevsky, A., Schlecter, M., \& Netter, S. (2007). Maternal and parental Parenting style in adolescent: Associations with self-esteem, Depression and life satification. J Child Fam Stud., 16, 39-47. doi: 10.1007/s10826-0069066-5.

Musianto, L.S. (2002). Perbedaan pendekatan kualitatif engan pendekatan kualitatif dalam metode penelitian. Jurnal Manajemen dan Kewirausahaan, 4 (2), 123-136. https://doi. org/10.9744/jmk.4.2.pp.\%20123-136.

Novyaningrum, E. (2013). Pola pengasuhan keluarga anak jalanan sebagai penyebab perilaku menyimpang anak jalanan (Skripsi, tidak dipublikasikan). STKIP Jombang, Jawa Timur.

Pamela, E., \& Waruwu, F.E. (2006). Efektivitas LVEP (Living Values: an Educational Program) dalam meningkatkan harga diri remaja akhir. Jurnal Provitae, 1 (2), 12-20.

Purwoko, T. (2013). Analisis faktor-faktor penyebab keberadaan anak jalanan di Kota Balikpapan. Journal Sosiologi, 1 (4), 13-25.

Santrock, J.W. (2005). Adolescence (10th Ed.). New York: The McGraw Hill Company.

Santrock, J.W. (2007). Children devepolment (7th Ed.). New York: The McGraw Hill Company.

Saripudin, D. (2012). The street children development in open house. Journal of Social Scientist, 8 (2), 267-273.

Shukla. (2006). Child labour and the law. New Delhi: Sorup \& Sons. 
UNESCO. (2010). Street Children. Januari 15, 2015. Diperoleh dari http://www.unesco.org/ new/en/social-and-human-sciences/themes/ fight-against-discrimination/education-ofchildren-in-need/street-children/ 